\title{
Gender-based Violence: Conceptions of Professionals on the Family Health Strategy's Teams
}

\author{
Neusa Maria Franzoi ${ }^{1}$ \\ Rosa Maria Godoy Serpa da Fonseca² \\ Rebeca Nunes Guedes ${ }^{3}$
}

This study is the result of a survey carried out with professionals of the Family Health Strategy's teams (FHS) in Araraquara, SP, Brazil. The study analyzed the conceptions held by FHS professionals concerning women, men and gender-based violence from the perspective of gender. The theoretical and methodological framework used was composed of gender and gender-based violence as social constructs guiding health practices. Empirical data were obtained from workshops and submitted to content analysis. The coexistence of critical and potentially transforming conceptions with conservative ones that reproduce the hegemonic ideology of male dominance was observed. These results confirm the need to broaden professional education to enable workers to deal with gender-based violence, which is a common element in the routine lives of women seeking health services.

Descriptors: Violence Against Women; Women's Health; Family Health.

\footnotetext{
${ }^{1}$ Social Work Assistant, M.Sc. in Public Health Nursing, Coordenadoria de Assistência Social, Universidade de São Paulo, SP, Brazil. E-mail: nefranz@usp.br.

${ }^{2}$ RN, Ph.D. in Nursing. Full Professor, Escola de Enfermagem, Universidade de São Paulo, SP, Brazil. E-mail: rmgsfon@usp.br.

${ }^{3}$ RN, Doctoral Student, Programa Interunidades de Pós-graduação em Enfermagem, Escola de Enfermagem da Universidade de São Paulo and Escola de Enfermagem de Ribeirão Preto da Universidade de São Paulo, Brazil. E-mail: rebecanunesguedes@gmail.com.
}

Corresponding Author:

Neusa Maria Franzoi

Universidade de São Paulo. Escola de Enfermagem

Departamento de Saúde Coletiva

Av. Dr. Eneas Carvalho de Aguiar, 419

Vila Clementino

CEP: 05403-000 - São Paulo, SP, Brasil

E-mail: nefranz@usp.br 


\section{Violência de gênero: concepções de profissionais das equipes de saúde da família}

Este artigo é resultante de pesquisa junto a profissionais das equipes do Programa de Saúde da Família (PSF), do município de Araraquara, SP, e teve como objetivo conhecer e analisar, à luz de gênero, as concepções de profissionais das equipes de saúde da família desse município em relação à mulher, ao homem e à violência de gênero. 0 referencial teórico-metodológico foi constituído pelo gênero e violência de gênero, como construtos sociais norteadores das práticas em saúde. Os dados empíricos foram obtidos em oficinas de trabalho e submetidos à análise de conteúdo. Constatou-se a coexistência de concepções críticas, potencialmente transformadoras, com outras conservadoras e reprodutoras da ideologia hegemônica da dominação masculina. Tais resultados confirmam a necessidade de ampliar a qualificação profissional no sentido de capacitar os trabalhadores para lidar com o fenômeno da violência de gênero, comum no cotidiano da vida das mulheres que buscam os serviços de saúde.

Descritores: Violência Contra a Mulher; Saúde da Mulher; Saúde da Família.

\section{Violencia de género: concepciones de profesionales de los equipos de salud de la familia}

Artículo resultante de una investigación entre profesionales de los equipos del Programa de Salud de la Familia (PSF) del municipio de Araraquara (SP) que tuvo como objetivo conocer y analizar, bajo la perspectiva de género, las concepciones que los profesionales de los equipos de salud de la familia de ese municipio tienen en relación a: mujer, hombre y violencia de género. El referencial teórico metodológico fue constituido por el género y la violencia de género como constructos sociales orientadores de las prácticas en salud. Los datos empíricos fueron obtenidos en Talleres de Trabajo y sometidos al análisis de contenido. Se constató la coexistencia de concepciones críticas, potencialmente transformadoras con otras conservadoras y reproductoras de la ideología hegemónica de la dominación masculina. Esos resultados confirman la necesidad de ampliar la calificación profesional en el sentido de capacitar a los trabajadores para lidiar con el fenómeno de la violencia de género, común en lo cotidiano de la vida de las mujeres que buscan los servicios de salud.

Descriptores: Violencia Contra la Mujer; Salud de la Mujer; Salud de la Familia.

\section{Introduction}

Even though society is in constant transformation, it produces and reaffirms androcentric values that reinforce asymmetry and power in relationships between men and women, which brings about serious problems at its core, such as gender-based violence. Gender-based violence may be defined as "any act of ... violence that results in, or is likely to result in, physical, sexual or mental harm or suffering to women, including threats of such acts, coercion or arbitrary deprivation of liberty, whether occurring in public or private life"(1).
Research reveals that between one quarter and more than half of women in the world report physical abuse by current or previous partners ${ }^{(2)}$. Rape and domestic violence result in disabilities and the death of productive women. Such violence similarly reaches between $25 \%$ and $50 \%$ of women in the Latin American and the Caribbean ${ }^{(1)}$.

A study carried out in 14 public health services in Brazil revealed that about one quarter of women suffered severe abuse from a close partner, including blows, 
burns, or from use of weapons. About 20\% reported abuse during pregnancy ${ }^{(3)}$. Despite the high frequency with which gender-based violence occurs, it is not totally visible given underreporting of cases. Another factor is its devaluation as a social problem, violation of women's rights, and as a context conducive to the development of health problems. Underreporting occurs due to the difficulty in diagnosing and recording such violence. In one of the studies in the field, $68.75 \%$ of reports of abuse were considered casual occurrences ${ }^{(4)}$.

Domestic and sexual violence greatly influence the way and life of women in diverse social contexts, significantly affecting the health-disease continuum of women experiencing such problems. Women suffering domestic and sexual violence present more health problems, generate more costs in terms of health care and constantly seek more hospital and emergency services than women who do not suffer abuse(2). As a social problem, it belongs to the scope of law and public security and is an object of social movements. Therefore, care provided to these women is not exclusive to health services but part of various sectors of the society that should act together. This cooperation appears in the enlarged conception of health and disease as a social process, referring to any harm or threat to life, working conditions, interpersonal relationships, quality of life and general existence. On the other hand, one needs to enlarge the view of the problem and health care to include the perspective of gender, aiming to overcome hegemonic social values that naturalize inequality and justify oppression and violence against women.

Health professionals bring values that are internalized by the construction of gender identities within the routine of their practices, ${ }^{(5-6)}$. In women's health care, these constructs often translate into the omission of effective care, solidarity and protection. They also hinder professional practice as an instrument of individual and social emancipation(5).

The Brazilian Unified Health System (SUS) consolidated the Family Health Strategy (FHS) as the main strategy to reorganize primary health care. The territorialization of health care within the FHS has enabled a greater establishment of bonds and closeness between professionals and users of health services, unveiling previously obscure or unrecognized problems as objects susceptible to intervention in the health field, as is the case of gender-based violence. These proposals have as their main challenge the promotion of reorienting health practices and actions in an integral and continuous way, bringing them closer to the family(7). Hence, this closeness between health professionals and health services users from the scope areas favors empathy required to address complex subjects such as violence(8). However, in the scope of care provide to women who experience sexual violence, studies reveal that FHS professionals do not feel prepared to deal with the problem, defining their work as paralyzing powerlessness, which refers to historical gaps in professional education and the organization of services to heed needs produced by violence ${ }^{(9)}$.

The national heath policy established in the SUS and consequently the FHS assumes a health care practice that enlarges the object of work beyond mere biology, considering ways of working and living in society as significant determinants of the health-disease continuum. However, this policy has not, in some aspects, been concretized in the routine of practices, since professionals historically have not been given specific technologies to address complex problems that escape the singular and biologist logic of health care.

On the one hand, care is directed to understand patients assertively, because its final objective is to meet the health needs of the collective. Contrary to this principle, though, studies addressing the subject have revealed that health practices, focused on women who experience violence, have been de-gendered. One result is that care delivery does not always take into account the asymmetry of power between men and women that results from broader social processes determinant in gender-based violence.

Additionally, health professionals bring to the routine of their professional practice their construction of gender identities, revealing a care practice often impregnated with preconceptions that reaffirm inequalities. This construction determines the professional's subjectivity, influencing the way they recognize problems and how they cope with them. Moreover, it results from a historical and ideological process impregnated with an andocentric preference that permeates the entire social structure.

From this perspective, to transform health practices through giving tools to professionals, one has to understand how health professionals view the world concerning the social construction of gender identity and gender-based violence. Guiding knowledge is the main tool health professionals use in this process and their work, which determines a practice that either overcomes or reiterates inequalities. Hence, the proposal to implement the qualification of health teams in the services, should consider the knowledge and ideology guiding professionals' practices. 
Based on the preceding discussion, this study's object includes the conceptions of gender-based violence held by FHS professionals. Such an understanding can provide elements both to qualify these professionals in caring for victims of gender-based violence and to design care policies to overcome such violence. Additionally, it can introduce a critical view in regard to how these professionals intervene in the health-disease continuum of women in a connected way in order to heed their needs. To achieve such a goal, this study identifies and analyzes the conceptions of professionals from FHS teams in the city of Araraquara, SP, Brazil in relation to women, men and gender-based violence seeking to make clear contradictions that permeate such conceptions from the perspective of gender.

\section{Method}

This is a qualitative study, the discursive elements of which were analyzed from the perspective of gender. The empirical material was collected in three sessions of a workshop carried out with 95 health professionals (90 community health agents and five nurses) who composed 12 FHS teams in Araraquara. The objective was to encourage them to reflect upon violence against women. One of the activities included in the month in which the International Day of Non-violence Against Women is celebrated on the $25^{\text {th }}$. Among the celebrations of 2005, the realization of this study was planned to strengthen the idea of combining research and social intervention. About $85 \%$ of the group was composed of women, ages varying from 21 to 45 years old, with a secondary education or above. Almost half (40\%) had some college or had already a bachelor's degree.

Araraquara is located in the central region of the state of São Paulo, Brazil and has a population of about 200,000 inhabitants with a reasonable level of social development. "Araraquara improved its position in the Economic Development Index from the Metropolitan Studies Institute (IEME). The city occupied the $19^{\text {th }}$ position in 2003. (...) Among the cities in the interior [state of São Paulo), Araraquara is in $10^{\text {th }}$ position [2004]" (10).

The participants of the workshop were divided into two groups (morning and afternoon). Three sessions of four hours each were carried out with each group, totaling 12 hours. In the first session, conceptions of man, woman and gender-based relationships were discussed. In the second session, the phenomenon of violence against women was discussed and then the professional practices within the FHS scope were discussed in the third session. Facilitating strategies such as the construction of panels with sculptures made out of fabric, the use of modeling clay and dramatizations of real situations when care is provided were used; these were described by the participants themselves.

Data obtained in the reports of the projects of each group in each stage of sessions were recorded and transcribed verbatim. Themes related to the object of study were chosen to compose the discursive set of this study. The testimonies were submitted to content analysis to extract empirical categories, which in turn, were submitted to analysis using analytical categories of gender and gender-based violence.

In its general contours, the category gender assumes a historical construction of social relationships between genders, distinguishing the biological from the social. "The essential core of the definition is based on two propositions: gender is an element constitutive of social relations based on differences between sexes and the primary way to signify power relations"(11).

Gender is defined in relation to another and connects and acts with other social categories - generation, race, ethnicity, class, profession, and sexuality - in a diverse manner. As an instrument of analysis, it leads to a review of ideology of male dominance. As a consequence, gender-based violence is also a historical category that originates from the domination of men over women. It can, therefore, clarify and enable the understanding of the social determinants of phenomena of women's lives, among them, gender-based violence.

\section{Ethical aspects}

The study integrated the project "Professional practices and violence against women: a study of gender and social class", the research protocol of which was approved by the Research Ethics Committee at the University of São Paulo, Nursing School. All the ethical aspects related to research involving human subjects were observed according to Resolution 196 from October $10^{\text {th }}, 1996$, National Council of Health. Workshops have been widely used by the Research Group on Gender, Health and Nursing at the Collective Health Department, University of São Paulo, School of Nursing and have been a powerful methodological instrument to be used in research addressing gender, since group experience enables a greater understanding of meanings and subjectivities that permeate phenomena related to processes of constructing femininity and masculinity in the studied context. Before initiating the activities of each workshop, the participants were told that meetings 
would be used to collect data according to the study's objectives. They were also informed at the time that the decision to participate in the study was voluntary and they were free to consent to participate in the study or not, and likewise for the workshops. Those who consented signed free and informed consent forms.

\section{Results and Discussion}

Four empirical categories emerged from the analysis:

\section{Women and men: equality and difference, roles and identities}

The participants acknowledged that the human being, when becoming a woman or man in the socialization process, acquires his/her identity. Gender identities are socially unstable constructs, such as feminine and masculine. Individuals construct themselves, arranging and disarranging their social places, dispositions, ways of being in the world given social relationships, discourses, symbols, representations and practices. Such constructions and arrangements are always transitory and are historically transformed(12).

Gender identity is revealed through social behavior or roles associated with femininity and masculinity. Hence, FHS professionals reproduced gender stereotypes in their conception. Due to these conceptions, men feel good in protecting patients and therefore determining who has and exercises power. However, they also have characteristics considered feminine such as neediness and dependency. In relation to women, even though they currently are more active in the public sphere, they are also responsible in the private space for domestic chores and maternal duties, revealing the heterogeneity of being a woman in the diverse social spaces she occupies. The following excerpt illustrates this idea:

Men feel good in protecting, maintaining, but they are also needy, are dependent. Women seek to protect also, to be the supporter. Today, this is the women's role also, because women are mothers, sensitive and fighters.

The testimonies reveal that maternity reaffirms feminine roles, linked to the natural world, to nature and its cycles; such a conception is idealized and does not consider potential problems faced in gender relations.

Nature is represented by green, because women represent as if they were the cycles of nature, she gives life also, gets pregnant.

The logic of relationships of domination imposes and instills in men and in women negative proprieties that the sexist ideology attributes to the female nature. The patriarchal-androcentric view continually confirms and legitimates the very practices it determines, leading men and women to internalize unfavorable preconceptions against the feminine. Hence, male dominance has favorable conditions to fully exercise itself because it is incorporated in the entire social structure ${ }^{(13)}$.

In general, professionals represent men and women in their physical differences, force and physical makeup. The set of male physical attributes is a historical argument used to disseminate the patriarchal ideology, representing male superiority justified by biological attributes.

A man is represented by a tie because he is physiologically stronger. There is no way to compare the body, sometimes physiologically of a man and a woman, men have a stronger structure than women.

It is common to hear that women are different from men and they differ because men are taken as the standard and female is the second gender. The differences between genders are primarily related to the biological, physical, psychological, and behavioral spheres, as well as abilities. This perception is supported by theories constructed to historically justify social roles, possibilities and destinies of each gender ${ }^{(12)}$. This difference is shown as an apparently truthful dichotomy, since equality -a political concept-assumes there is a difference and there is no sense in demanding equality. Rather one should demand equivalence, since individuals are not identical. It is important to take into account historicization in the deconstruction of the terms of sexual differences ${ }^{(11)}$.

Hence, the relationships between genders, both in the private and public spheres, are characterized by an asymmetry of power. The sociocultural construction of female identity and definition of women as passive and submissive creates a space conducive to the exercise of male oppression over women, which can be translated into violence ${ }^{(5)}$.

\section{Overcoming differences}

Most professionals reported the differences between women and men in terms of biology. Contradictorily, they see in their children the transforming possibilities of these relationships.

This man and this woman create a relationship from which children are born, we've got to the conclusion that these children should simply be preserved in their innocence so that they get into a line of life in which they can change the differences that are currently perceived. 
Formal education and means of communication, among other forms in which social consciousness is disseminated, transmit new ways of acting and thinking to children, including gender identity. Transformations in the naturalization of the subordination of women by men are even now observable. A study conducted in the United States revealed that children raised primarily by their fathers were more flexible in terms of traditional roles of gender than those raised in families with more orthodox customs ${ }^{(14)}$. The professionals expressed that overcoming inequalities in the relationships of gender can also be enabled through formal education.

Women and men can have an academic degree because we are human beings, and both have the right to develop, grow and acquire knowledge.

In the case of relationships between genders, fairness, more than equality, is what is sought. "Adopting equality of gender as an ethical concept associated with principles of social justice and human rights does not imply belittling or putting off the rights of men to privilege women (...) It is about looking at it from a new perspective, with diligence and care, looking at the situation of millions of women who suffer inequities in their daily lives, becoming outraged with their situation and move toward transformation. This does not confuse, however, their right to dignified and respectable care because these women are citizens and it is imperative to have them healthy and productive since they generate and maintain the current and future workforce, whom society depends on for the generation of social wealth"(15).

\section{Gender-based violence: what FHS professionals think}

It is known that every discourse is ideologically situated and every interpretation is historically constructed, learned and grasped. Hence, it is mainly the social construction of gender that is responsible for the naturalization of violence, both by men and women. The professionals revealed the cultural barrier that supports violence as a difficult habit to be broken, since values are deeply rooted. They mentioned, however, the influence of culture in the construction of women and men, as the following excerpt shows:

(...) we put a cultural barrier, sometimes women themselves think this is not violence, they were raised like this, treated like this, which is normal, which is right, so they don't see it as violence.

The naturalization of violence in relationships such as historical and cultural processes correspond to an androcentric ideology that permeates society and is carried and learned over the course of history, so that even in the face of all the transformations society has undergone in relation to hegemonic values, the ideology of male dominance and the naturalization of violence is reiterated. Even today, abuse become routine and is aggravated with time and is generally seen by women as destiny. From being normal, violence moves to being banal and is seen as an integrating part of an affective relationship. Even though it may happen among affective partners of both sexes or the same sex, there is a gender character because it results from the social construction of men and women in asymmetric relationships in which one of them has more power and authority ${ }^{(16)}$.

The hegemonic and andocentric ideology conceives the female nature from a perspective that limits women-their feelings, thoughts and actions-to the private sphere of the domestic and procreative world ${ }^{(16)}$. Studies indicate that women do not recognize situations of violence experienced in intimate relationships as such. It reveals, in practice, that not only do men, but also women carry with them the naturalization of male dominance and violence of men against women. This aspect constitutes one of the limitations in coping with the phenomenon and the transformation of the culture of female subordination ${ }^{(17)}$.

The persistence of many women remaining in relationships in which they are submissive to male power involves a range of factors, from economic or affective dependence of partners, to the supposed gratification that a relationship brings, to personal realization of maintaining the idealized model of woman who sustains an affective relationship and a nuclear family, even if she has to cancel herself as human being ${ }^{(5)}$.

In relation to women who provide for the family, health professionals highlight that culture also interposes in the dissolution of marriages, even if to maintain a marriage one needs to use violence. They reported that the abused woman might not even recognize herself as the one who provides, supporting abuse in the name of the family and culturally imposed conventions.

It is a cultural barrier. There was a case like this: the woman was the provider; she'd pay for everything. She was independent but culturally she felt that the children, the family could not be dissolved, even having a husband who was alcoholic. He'd beat her, on her head, she really believed that from the moment she married that man, she should stay with him to raise her family.

Women are increasingly becoming the economic providers of families. From this perspective, cultural 
aspects such as a change of values, individualization processes and the autonomy of women given work and an increased level of education, may have broken with part of the tradition of exclusive male authority, which may determine tensions in unequal inter-gender relationships. The autonomy of women in sexual and reproduction terms may also be a source of tension because it denies men as regulators of female sexuality ${ }^{(16)}$.

Professionals also stated that the war always start at home, referring to gender-based violence that occurs in the family sphere due to a lack of mutual respect. However, this discourse disregards the possibility that conflict may reside in the imminence of loss of status quo on the part of men and the progressive occupation of this space by women, which in turn may trigger resistance.

Men and women first need to mutually respect themselves to give continuity to the life cycle: these conflicts only lead to violence: moral, physical, psychological, etc., not allowing the other to grow and develop as a human being. War always starts at home.

The growing independence of women, with their counter-cultural actions coupled with the change of patterns of paternal authority, possibly worsens gender relations in which acts of females overcoming barriers is isolated and gradually being constructed. Hence, women are not able totally to break with subordination because it is moved by ideological mechanisms of the reproduction of the status quo, which are only overcome in the construction of new social relations, which requires the deconstruction of what is currently hegemonically established as responsibilities of men and women ${ }^{(5)}$.

\section{Frail woman, strong man: an unequal relationship generating violence}

Professionals reported that the low self-esteem of women allow men to perpetrate violence, linking it to female fragility.

(...) a bit of a lack of self-esteem in women; that is why they permit another to abuse them, both physically and psychologically.

Self-esteem may be understood as the value one attributes to oneself, acquired through living together with peers and other individuals in the space of social relationships. Hence, it is also a result of a social construction that can be encouraged or minimized depending on the quality of partnerships and relationships. When these are worn out or undermined as in the case of violent relationships, the result is low self-esteem, which in turn demotivates and demobilizes transformations. Hence, it encourages not only the continuity of violent relationships but also negatively interferes in the possibility of transformation. Therefore, one cannot say that low self-esteem determines violent relationships, but it certainly does contribute to its perpetuation.

The study's participants reinforced stereotyped values such as the vanity of women and the need to be beautiful. The requirement is applicable even for women who experience violence. Being an external quality, beauty can be produced to disguise abuse. Such discourses are dangerous because they may suggest that women should camouflage violence through appearances and consequently reiterate androcentric values. For them, losses experienced by women - selfesteem, the desire to be beautiful - in addition to fear and shame from society, make them incapable of coping and overcoming relational hardships.

We put (as cause of violence) low self-esteem, loss of vanity, insecurity, fear and shame of society, she starts to feel incapable.

The perception that women feel incapable can put them in the position of the victim, unable to react; a discourse that denies the dynamicity and possibility of transforming relationships. Hence, when women, men, health professionals and society in general think about the permanence of individuals in violent relationships as destiny, they put them in the role of victims; they themselves victimize women. Even though male dominance is internalized in feminine imagery, it does not mean that women are responsible for their own oppression, consciously choosing it or feeling gratified for adopting submissive practices. Female submission is often mentioned as an excuse to blame the victim but it is important to point out that this construction is not a conscious act but rather it results from ideological mechanisms that are occult or dissimulate the truth(5).

The fact that women live years in situations of violence considerably affects their self-esteem and trust, diminishing their ability to act and fully participate in society. Additionally, in general they do not seek support for solving the problem because they think their demands will not be acknowledged and they feel they have no options in the face of limited chances to change, which hinders any initiative to cope with violence. Such immobility also combines with gender-based violence to diversify and aggravate over time, becoming more intense and frequent, if appropriate intervention is not implemented to stop the escalation of facts ${ }^{(17)}$. 
Hence, coping with gender-based violence as a destructive phenomenon of the life processes of women should take into account that its determination occurs both in the social structure and the dimension of groups and individuals and families, whose strong component is the ideology that permeates gender relations. It is essential that health services identify and understand the problem in depth to cope with it in a manner different from the hegemonic one, which reproduces the dominant oppressive ideology ${ }^{(18)}$.

This study revealed a view based on the ideology of male dominance in relation to the meanings that permeate the determination of gender-based violence. This aspect can determine contradictions in the core of the practice related to it. In the face of a lack of technological preparedness of health services to deal with the phenomenon, investments are needed to make professionals feel prepared to devise strategies to identify and intervene in the collective, jointly with the Family Health Strategy ${ }^{(19)}$.

\section{Final considerations}

This study analyzed the conceptions of the FHS health professionals in Araraquara, SP, Brazil concerning gender-based violence, based on and linked to the conceptions of men and women. The results showed that despite advancement toward a more critical view concerning the influence of the processes of construction of masculinity and femininity in gender identity, conservative views coexist with them. They reaffirm stereotypes that agree with folk beliefs, revealed for instance in the conception of the man-provider (rational, strong, who should command) and the reproductivewoman (emotional, fragile, who should obey), which reinforces socially established roles.

The coexistence of different ways to understand women and men is a consequence of changes that are occurring in relationships based on the increased participation of women in the public world, which enabled them to improve their independence. Even though these changes have not been extreme, they are operative in transformations in women's conduct and positions, making then stronger in the relationships they establish with men, which contributes to gradually redefining their gender roles in the family sphere.

This movement is socially perceived and is instrumental for transformations to also occur in individuals' conceptions of gender since gender is an element of one's identity. Considering that subjectivity is also historically determined, when the professionals reveal their more traditional concepts or their tentatively more innovative concepts of gender, they also reveal their repertory of gender and it shows that they are subjects in construction.

Finally, it seems important to reaffirm that considering violence against women a social problem implies not only giving more visibility to the problem but also devising a special way to address the issue. Hence, the conception of violence as an individual problem that is a consequence of some situation or singular circumstance is opposed to the consideration of violence as a social problem, with violence against women having its origin in unequal social relationships. In that case there is an emphasis on a social contract between men and women that implies the oppression of one gender (the female gender) by another (the male gender).

\section{References}

1. Convenção de Belém do Pará. 10 anos da adoção da Convenção Interamericana para Prevenir, Punir e Erradicar a Violência contra a Mulher. In: Convenção de Belém do Pará. 3 ed. Brasília: Agende; 2005. p. 14-5.

2. Minayo MCS. Violência e saúde. Rio de Janeiro: FIOCRUZ; 2006. 132 p.

3. Durand JG. Gestação e violência: estudo com usuárias de serviços públicos de saúde da grande São Paulo [dissertação]. São Paulo: Faculdade de Medicina/USP; 2006. 220 p.

4. Santos LL. A visibilidade da violência de gênero em dois serviços de assistência primária à saúde [dissertação]. Ribeirão Preto: Faculdade de Medicina de Ribeirão Preto/ USP; $2003.142 \mathrm{p}$.

5. Guedes RN, Silva ATMC, Coelho EAC. Violência conjugal: problematizando a opressão das mulheres vitimizadas sob olhar de gênero. Rev Eletr Enferm. [Internet]. 2007;9(2):362-78. [acesso 15 março 2007]. Disponível em: http://www.fen.ufg.br/revista/v9/n2/ v9n2a06.htm

6. Andrade CJM, Fonseca RMGS. Considerações sobre violência doméstica, gênero e o trabalho das equipes de saúde da família. Rev Esc Enferm USP. 2008;42(3):591-5.

7. Programa Saúde da Família. Rev. Saúde Pública [Internet]. 2000;34(3):316-19 [acesso 05 dez 2010 ]; Disponível em:http://www.scielo. br/scielo.php?script=sci_arttext\&pid=S0034$89102000000300018 \&$ Ing=en. doi: 10.1590/S003489102000000300018 
8. Batista KBC. Violência contra a mulher e programa saúde da família: a emergência da demanda na visão dos profissionais [dissertação]. São Paulo: Faculdade de Medicina da Universidade de São Paulo; 2003. 148 p.

9.Oliveira CC, Fonseca RMGS. Práticas dos profissionais das equipes de saúde da família voltadas para as mulheres em situação de violência sexual. Rev Esc Enferm USP. 2007;41(4):605-12.

10.Gardim R. Araraquara sobe para $17^{a}$ no IDEE. Tribuna Impressa. 31 de julho de 2004. [acesso 05 dez 2009]. Disponível em: http://www.jornaldeararaquara.com.br/ home. pas ?codmat $=18988 \&$ pub $=2 \&$ edicao $=$ twwqcvmqe cqjx

11.Scott J. Gênero: uma categoria útil para a análise histórica. 2a ed. Recife: SOS Corpo; 1995. 26 p.

12.Louro GL. Gênero, sexualidade e educação: uma perspectiva pós-estruturalista. Petrópolis: Vozes; 1997. $179 \mathrm{p}$.

13. Bourdieu P. A dominação masculina. Rio de Janeiro: Bertrand Brasil; 2003. 160 p.

14.Siqueira MJT. Novas formas de paternidade: repensando a função paterna à luz das práticas sociais. In: Silva AL, Lago MCS, Ramos TR, editors. Falas de gênero. Florianópolis: Mulheres; 1999. p. 187-202.

15.Fonseca RMGS. Investigando, construindo e reconstruindo a enfermagem generificada através das Oficinas de Trabalho. In: Anais do 20 Encontro Internacional de Pesquisa em Enfermagem: Trajetória Espaço-Temporal da Pesquisa; 2002. 28-31 outubro; Águas de Lindóia [CD-ROM]. São Paulo: EEUSP; 2002.

16.Schraiber LB, d'Oliveira AFPL, Falcão MTC, Figueiredo WS. Violência dói e não é direito: a violência contra a mulher, a saúde e os direitos humanos. São Paulo: Unesp; 2005. 184 p.

17. Heise L. Gender based abuse: the global epidemic. Cad Saude Publica. 1994;10(Supl 1):135-45.

18.Guedes RN, Silva ATMC, Fonseca RMGS. A violência de gênero e o processo saúde-doença das mulheres. Esc Anna Nery Rev Enferm. 2009;13(3):625-31.

19.Fonseca RMGS, Egry EY, Leal AERB, Skubs T, Guedes RN. Violência doméstica contra a mulher na visão do agente comunitário de saúde. Rev. Latino-Am. Enfermagem. 2009;17(6):974-80. 